\title{
HIGHER THAN THE ORIGINAL STANDS THE TRANSLATION: TRANSLATING HEIDEGGER INTO FILIPINO
}

\author{
Remmon E. Barbaza \\ Ateneo de Manila University \\ rbarbaza@ateneo.edu
}

\begin{abstract}
This paper is a reflection on the author's experience of translating Martin Heidegger into Filipino. It first addresses the questions of principles underlying the act of translation, such as those of fidelity (to both source and target languages, original author and translator), as well as the role of the translator as an intermediary between the original author and the readers. Then it demonstrates examples of his experience of translating selected key terms and passages in Heidegger-such as sein, stellen, Ereignis, and their cognates-indicating the difficulties as well as the challenges that arise in the work of translation. A notable problem or challenge is the absence in Filipino (as in other Austronesian languages) of the verb "to be," one of the most important subjects of philosophical inquiry in the Western tradition. It ends by reflecting on this experience of translation, noting how even the German concept of Übersetzen and that of the Filipino salin may lend themselves to a "fusion of horizons," and how, in the Heideggerian sense, translation may be said to stand higher than the original.
\end{abstract}

\section{Keywords}

hermeneutic tradition, Seinsfrage, Ferriols, meron, event, actuality, possibility

\begin{abstract}
About the Author
Remmon E. Barbaza is Associate Professor of Philosophy at the Ateneo de Manila University. He earned a Ph.D. in Philosophy from the Munich School of Philosophy in 2002, under the supervision of Prof. Dr. Gerd Haeffner, S.J. His dissertation, Heidegger and a New Possibility of Dwelling, was published in 2003 (Frankfurt: Peter Lang). His essay, "There Where Nothing Happens: The Poetry of Space in Heidegger and Arellano," appears as a chapter in the second, expanded edition of Heidegger and the Earth: Essays in Environmental Philosophy (Toronto: U of Toronto P, 2009). He served as the Chair of the Department of Philosophy at the Ateneo de Manila, and currently works as associate editor of the Budhi: A Journal of Culture and Ideas. His research interests include Heidegger, technology, the city, environment, language and translation.
\end{abstract}


IN TRANSLATING TEXTS WITH PRACTICAL OBJECTIVES (such as in the case of a scientific experiment or a user's manual for a kitchen appliance), one does not need to look back to the source language for as long as the practical objective is indeed achieved. One can even completely ignore the source language. Even the target language is not as important for as long as the practical results are realized. One can allow for a little imperfection here and there, in grammar or construction, as long as the intended goals are met.

But not so in the case of translating a literary or philosophical text. Here, one has to keep looking back to the source language. And not only look back: one has to keep looking back and forth, between source and target languages for fidelity in translation is not one-way-one has to be faithful to both source and target languages. Without this two-way fidelity, one can do violence to both the original author or text and the intended audience or target language.

The question of fidelity in translation, however, is not just one about the object of fidelity, but what exactly is meant by it, if not indeed whether one should take fidelity in a simplistic way. Susan Jill Levine, for example, reminds us that the only way to render the old translation adage, traduttore, traditore, is to be "a faithfully unfaithful translator" (85). Thus, a translation becomes faithful by being unfaithful, and is hence not simply another version of the original, but a "subversion" (88). This insight is not quite unlike what one hears from within the hermeneutic tradition, namely, that the original text remains the same only by being interpreted differently each time. When the translator or interpreter does not bring in her own originality in the work of translation, she ends up with something that is lifeless, a mere repetition of the original that could otherwise have simply been carried out by a recording machine. Being faithfully unfaithful, remaining the same by always being different-these are no mere play of words, but an indication of the complex and dynamic character of the act of translation, that it is as creative a work as the writing of original texts.

The issue of how we are to understand this back-and-forth glance, this intermediary role of the translator, indeed the very possibility of translation itself, is understandably contentious. One extreme position is that translation itself (taken in this sense of the to-and-fro glance, this double fidelity) is impossible. The other extreme perhaps is one where the translator assumes he is not in any way bound by either the source or target language, and therefore proceeds with the work in any way he wants.

If we are to follow Aristotle's practical advice on how to find the right measure between two extremes, then we might do well to stay closer to the harder extreme (1109b, 1-5), which is to say that we never lose sight of the impossibility of translation, even as we are driven by its necessity, and hence make it possible-possible yet never final (and hence the impossibility). "Translation is forever impossible and forever necessary," says Edward Seidensticker, alluding to Allen Tate (153). One might say that this double glance of the translator is directed not only to the source 
and target languages, but also to the impossibility and necessity of translation. The translator's fidelity is also the honest recognition of the impossibility as well as the surrender to its necessity. In an eloquent confession, Gayatri Chakravorty Spivak says, "Translation is the most intimate act of reading. I surrender to the text when I translate" (201).

It is within this context of impossibility and necessity, this double glance of the translator, that I wish to reflect on my experience of translating Heidegger. Taking a position that is close to the harder extreme, George Steiner himself maintains that Heidegger is virtually untranslatable, insisting that Heidegger translations should always be bilingual. Citing the 1955 lecture "Was ist das-die Philosophie?", Steiner, whose English translation appears in a bilingual edition, notes: "This ought to be the case with all of Heidegger's writings, as recourse to the special terminology and grammatical structure of the original is virtually indispensable" (19). Steiner is right in pointing to the uniqueness of Heidegger in the history of thought, which consists in not only the inseparability of his thinking from the language he uses, but also the way he relates himself to that particular language, and to language in general.

How does Heidegger stand in relation to language? Perhaps the most telling passage in response to this question is the one we find in "Building Dwelling Thinking," whose formulation is at once crucially substantial as it is profoundly eloquent that quoting it here in extenso would be deemed justified:

It is language that tells us about the nature of a thing, provided that we respect language's own nature. In the meantime, to be sure, there rages round the earth an unbridled yet clever talking, writing, and broadcasting of spoken words. Man acts as though he were the shaper and master of language, while in fact language remains the master of man. Perhaps it is before all else man's subversion of this relation of dominance that drives his nature into alienation. That we retain a concern for care in speaking is all to the good, but it is of no help to us as long as language still serves us even then only as a means of expression. Among all the appeals that we human beings, on our part, can help to be voiced, language is the highest and everywhere the first. (146)

The above passage tells us quite clearly that Heidegger radically distinguishes his own understanding and experience of language from its dominant interpretation, which sees language merely as an instrument, and mainly an instrument of human communication (i.e., the instrumental and anthropological interpretation of language). We need to recognize, however, that in that passage, Heidegger uses the word "language" not in its ontic sense (i.e., in the sense of an actual, particular linguistic system, such as Japanese, Swahili, or French), but rather in its ontological 
sense (i.e., what makes a particular language language, the being-language of every language, just as we speak of the being human or humanity of human beings).

Proceeding from such an understanding and experience of language, what is to be said then of the work of translation? Insofar as translation happens through and in language, the translator then will not see her work as simply the transmittal of some intelligible content between two instruments, and that she as translator is in full command and control over these instruments. Rather, if ever there is to be talk of instrumentality, the translator becomes herself the instrument of this transmittal insofar as she listens to language, and speaks-translates-only as she hears, is spoken to, beforehand. Such a listening to language implies intimacy, about which we heard Spivak speak above and, still in another passage, says:

First then, the translator must surrender to the text. . . . no amount of tough talk can get around the fact that translation is the most intimate act of reading. Unless the translator has earned the right to become the intimate reader, she cannot surrender to the text, cannot respond to the special call of the text. (205)

The above considerations of double fidelity, between intimacy and surrender, between two languages brought into an encounter by translation, shape my own attempts at translating Heidegger into Filipino (here we recall Gadamer's concept of the Horizontverschmelzung, or "fusion of horizons" [311]). In what follows I present three examples as representative of the challenges that I face in translating Heidegger into Filipino, as well as two tables of further sample translations for which, given the limits of space, I could no longer provide explanations.

\section{"sein," "das Sein," "ein Seiendes"}

Easily the most difficult problem facing anyone attempting to translate Heidegger into Filipino is the absence of the existential verb "to be" (Ger. sein) in the latter, a lack it shares with other Austronesian languages. This is perhaps the most challenging problem given that the single most important question for Heidegger is the Seinsfrage itself, the question of being. The translation of Heidegger into English is difficult enough, as Derrida translator Alan Bass notes:

While the concept of Being belongs to the entire metaphysical tradition, its translation into English has become particularly difficult since Heidegger's analysis of it. German and French share the advantage that their infinitives meaning to be (sein, être) can also be used as substantives that mean Being in general. Further, in each language the present participle of the infinitive (seiend, étant) can also be used as a substantive meaning particular beings. No such advantage exists in English, and since Heidegger is always 
concerned with the distinction between Sein (être, Being in general) and Seiendes (étant, beings) the correct translation of these substantives becomes the first problem for any consideration of Heidegger. (xix)

In translating the German sein (or the English "to be") into Filipino, I find myself following the Filipino Jesuit philosopher Roque J. Ferriols. Born in 1924 and, as of the time of this writing, still teaching at the Ateneo de Manila University, Ferriols is credited for having been perhaps the first ever to teach philosophy using Filipino as the medium of instruction in the late 1960s, and doing so in the face of suspicion or doubt, if not hostility, from some of his colleagues (see Ferriols, Que and Rodriguez ). In expressing the concept or experience of being or existence, Ferriols uses the word "meron" (a contraction of "mayroon," which means "there is," but literally is composed of may, "there is," and roon, "there"). In ordinary usage, "meron" is used in utterances like the following: "Meron bang tubig sa banyo?" (Is there water in the bathroom?) "Meron ka bang barya?" (Do you have coins?). In philosophical discussions, one might say the following: "Meron ba talagang Diyos?" (Is there really a God?) "Meron akong dangal bilang tao." (I have dignity as a human being.) (See Ferriols 4-6.)

On several occasions, whether during class discussions or my personal conversations with him, Ferriols made it clear that "meron" is not to be taken simply as the equivalent of "being." To begin with, Ferriols would consider it a mistake to assume a one-to-one correspondence between languages. Nonetheless, the English word "being," the German "sein," and the Filipino "meron" to some extent do share the meaning of existence, each in its own way, each with its own possibilities and limitations. In Ferriols's usage, the conjugation of "meron" would allow one to say the following: "Ang pagmemeron ng tao" (The being of the human being), "Ang pagmemeron ng mga nagmemeron" (The being of beings), "Hindi maaaring magmeron ang wala" (What is not, cannot be).

It is interesting to note that the word "mayroon" is almost the literal equivalent of the German "Dasein," which in ordinary usage means "existence," but in Heidegger refers specifically to the being of the human being. Literally, "Dasein" means "there being," where "da" is "there" (or "here"), and "sein" of course is "being" or "to be." Both the ordinary German usage of "Dasein" and the Filipino "mayroon"/"meron" point to the experience of a "there." There is something out there, one might say. And the human being, the one who experiences the presencing of something out there, and utters such an experience, himself or herself stands out there, in the open, where, in Heidegger, the "there" or the "open" is itself the very world in which Dasein always already finds itself ("Sein und Zeit" 17). Heidegger also points to the fact that the word "existence" literally means to stand out (L. ex, "out," sistere, "take a stand"), and therefore reserves the word Existenz for Dasein, for only Dasein exists, only Dasein stands out there ("Sein und Zeit" 177). 
Perhaps equally interesting and significant is the happy discovery that Ferriols once shared in one of his philosophy classes, namely, that philosophy professors in Indonesia use the Bahasa Indonesian word $a d a$ to speak of being, even as, like Filipino and other Austronesian languages, that language does not have the verb "to be." Now, ada in Bahasa Indonesia is the equivalent of "mayroon" or "meron" in Filipino. Furthermore, the same word, "ada," actually exists in one of the major Philippine languages, namely, Ilocano, which means the same as it does in Bahasa Indonesia.

A closer consideration of may and mayroon might make us realize that may alone means "there is," that is, may alone utters the existence of something, and that strictly speaking it does not mean "to have"; it does not originally express possession. It is enough to say, "May Diyos," or "May tubig," to say "There is God," or "There is water," respectively. When one says, "May tubig ako," may in itself does not mean "to have." Only in the additional information provided by ako do we understand the secondary meaning of possession. Thus, "May tubig ako" means, "There is water, and it's in my possession." The primary indication is the existence of water, the secondary one is my possession of it. Thus, too, "Ako may tubig, ikaw wala," would mean, "There is water in my possession, there is no water in yours." This is also expressed in adjectives, which in most cases begin with the prefix ma- (e.g., maganda, matalino, mabait, mayaman). Maganda, for example, is a contraction of may ganda, which is to say, "There is beauty." Thus, Maganda si Maria would mean, "There is beauty in the case of Maria," or simply, "Maria is beautiful." There is Maria, there is beauty, and the two belong together.

Let me now turn to a second example in translating Heidegger into Filipino, namely, the verb "stellen" and its cognates.

\section{"Stellen" and Its Cognates}

In 1953, Heidegger delivered a public lecture titled "Die Frage nach der Technik" (The Question Concerning Technology) at the University of Technology in Munich. That lecture proved to be seminal and had far-reaching influence especially on the philosophy of technology. One indication of such influence is that even the more recent volumes on the "new waves" in the philosophy of technology could not quite do away with him, "whose ghost still looms" (Olsen, Selinger, Riis xi).

Perhaps the most important group of key words in that text is the one based on the root word "stellen." In a lengthy footnote, translator William Lovitt explains this group of words, which illustrate how the connectedness of the cognates in the original German is impossible to translate into English:

The verb stellen (to place or set) has a wide variety of uses. It can mean to put in place, to order, to arrange, to furnish or supply, and, in a military context, to challenge or engage. Here Heidegger sees the connotations 
of herausfordern (to challenge, to call forth, to demand out hither) as fundamentally determinative of the meaning of stellen, and this remains true throughout his ensuing discussion. The translation of stellen with "to set upon" is intended to carry this meaning. The connotations of setting in place and of supplying that lie within the word stellen remain strongly present in Heidegger's repeated use of the verb hereafter, however, since the "setting-upon" of which it speaks is inherently a setting in place so as to supply. Where these latter meanings come decisively to the fore, stellen has been translated with "to set" or "to set up," or, rarely, with "to supply."

Stellen embraces the meanings of a whole family of verbs: bestellen (to order, command; to set in order), vorstellen (to represent), sicherstellen (to secure), nachstellen (to entrap), verstellen (to block or disguise), herstellen (to produce, to set here), darstellen (to present or exhibit), and so on. In these verbs the various nuances within stellen are reinforced and made specific. All these meanings are gathered together in Heidegger's unique use of the word that is pivotal for him, Ge-stell (Enframing). (15)

The impossibility of translating Heidegger into English-in the case of the word "stellen" and its cognates-is not diminished in the case of Filipino translation. But the necessity of translation bids us to persist, to the best that we can. Here then are my proposed translations of this key group of words:

stellen, "itakdang-ayos." As we saw in Lovitt's commentary, the root word stellen is a verb that has a number of meanings. In my translation I have chosen to emphasize its sense of "setting" or "setting upon" (pagtatakda) as well as "setting or putting in order" (pagsasaayos). I therefore translate stellen as "itakdang-ayos." The following paragraph serves as an example:

Das bäuerliche Tun fordert den Ackerboden nicht heraus. Im Säen des Korns gibt es die Saat den Wachstumskräften anheim und hütet ihr Gedeihen. Inzwischen ist auch die Feldbestellung in den Sog eines andersgearteten Bestellens geraten, das die Natur stellt. Es stellt sie im Sinne der Herausforderung. Ackerbau ist jetzt motorisierte Ernährungsindustrie. Die Luft wird auf die Abgabe von Stickstoff hin gestellt, der Boden auf Erze, das Erz z. B. auf Uran, dieses auf Atomenergie, die zur Zerstörung oder friedlichen Nutzung entbunden werden kann. (Heidegger, "Die Frage nach der Technik" 16)

The work of the peasant does not challenge the soil of the field. In the sowing of the grain it places the seed in the keeping of the forces of growth and watches over its increase. But meanwhile even the cultivation of the field has come under the grip of another kind of setting-in-order, which sets upon [stellt] nature. It sets upon it in the sense of challenging it. Agriculture is now the mechanized food industry. Air is now set upon to yield nitrogen, 
the earth to yield ore, ore to yield uranium, for example; uranium is set upon to yield atomic energy, which can be released either for destruction or for peaceful use. (Heidegger, "Poetry, Language, Thought" 15)

Hindi sapilitang hinahamon ng gawain ng magsasaka ang lupang sinasaka. Sa paghahasik ng mga punla, isinusuko ang mga ito sa mga bisa ng pagtubo at iniingatan ang kanilang pagtubo at pagdami. Samantala ang pagpapatubo at pagpapataba ng lupa ay napasasailalim ng ibang uri ng pagsasaayos [Bestellen], na nagtatakdang-ayos [stellt] sa kalikasan. Ang pagsasaayos na ito ay nagtatakda sa kalikasan sa pakahulugan ng sapilitang paghamon dito. Ngayon, ang agrikultura ay ang mekanisadong industriya ng pagkain. Ang hangin ay itinatakdang-ayos upang makapagpalabas ng nitroheno, gaya ng pagtatakdang-ayos sa lupa upang makapagpalabas ng mineral, ang mineral naman upang makapagpalabas ng uranio, halimbawa; itinatakdang-ayos naman ang uranio upang makalikha ng atomikong enerhiya, na maaaring pakawalan tungo sa pagwasak o upang gamitin sa kapayapaan.

Let me now turn to my third and final example in translating Heidegger into Filipino, namely, Ereignis.

\section{“Ereignis," "sich ereignen," "zueignen," "übereignen," etc.}

In ordinary German, the reflexive verb sich ereignen means "to happen," and its nominative cognate, Ereignis, "event." In Heidegger, however, the word acquires a far more profound-and even obscure-meaning. Furthermore, Ereignis is, without doubt, one of the most central concepts in Heidegger. It is no coincidence either that it is also one of the most difficult Heideggerian terms to translate, whether into English or any other language. As if the word on its own is not enigmatic enough, it appears in the title of a book that Heidegger wrote between 1936 and 1938, but for which he specifically gave strict instructions that it not be published within his lifetime. The book was published for the first time in German in 1989 (thirteen years after his death in 1976), and in English translation in 1999. Entitled Beiträge zur Philosophie (Vom Ereignis), it appears as volume number 65 in the Gesamtausgabe or Collected Works.

A clear indication of the difficulty of translating this word can be gleaned from the circumstances and motivations behind the second English translation. The first English translation was carried out by Parvis Emad and Kenneth Maly and was released in 1999 as Contributions to Philosophy (From Enowning). Emad and Maly decided to coin a new word, "enown," in order to translate the verb sich ereignen, and thus "enowning" for the noun Ereignis. Among the reasons that led Emad and Maly to opt for a neologism was that the coined word "enown" expresses what is spoken in the German prefix er- and the root word eigen: 
We found a good approximation to Ereignis in the word enowning. Above all it is the prefix en- in this word that opens the possibility for translating Ereignis, insofar as this prefix conveys the sense of "enabling," "bringing into condition of," or "welling up of." Thus, in conjunction with owning, this prefix is capable of getting across a sense of an "owning" that is not "an owning of something" (xx).

We can also add that the word enowning has the advantage in that it follows the morphology of English verbs like "enable," "enlighten," "ennoble," and "empower," making it easier to decline or conjugate (unlike the more common translation, "event of appropriation," found in most secondary Heideggerian literature).

Highlighting the difficulty in and controversy surrounding the translation of Ereignis by Emad and Maly, an entirely new translation of the Beiträge appears 13 years after the first, in 2012. The new translators, Richard Rojcewicz and Daniela Vallega-Neu, did not hide their dissatisfaction with Emad and Maly's translation, which motivated them to translate it anew. Rojcewicz and Vallega-Neu opted to use the more common meaning of Ereignis, which is simply event.

How do I now propose to translate Ereignis into Filipino? I would like to capture both the sense of event as well as the owning or propriation. Thus I propose that we use kaganapan ("event," which also contains the word ganap, meaning "complete" or "fulfilled"), as well as angkop ("proper"). The word angkin ("to own") is another alternative, but if we are to avoid a lengthy formula such as kaganapan $n g$ pagangkop-angkin, and for the sake of simplicity choose only one verb between angkop and angkin, we can argue for angkop as being more inclusive, containing within it the sense of "owning" (angkin). For we can only own what is proper to us. What is proper belongs to us as something appropriate. Thus, we can render Ereignis into Filipino as kaganapan $n g$ pag-angkop, and sich ereignen as maganap ang pagangkop. Let me now offer some examples:

\section{Example 1:}

Das Ereignis übereignet den Gott an den Menschen, indem es diesen dem Gott zueignet. Diese übereignende Zueignung is Ereignis . ...." (Heidegger, "Beiträge zur Philosophie [Vom Ereignis]" 26)

Enowning owns god over to man in that enowning owns man to god. This "owning to" that "owns over" is enowning . . . (Heidegger, "Contributions to Philosophy: From Enowning" 20).

The event consigns [übereignet] god to the human being by assigning [zueignet] the human being to god. This consigning assignment is the appropriating event [Diese ubereignende Zueignung ist Ereignis] . . . (Heidegger "Contributions to Philosophy: Of the Event" 23) 
Iniaangkop-kaloob ng kaganapan ng pag-angkop ang diyos sa mga tao sa pamamagitan ng paghahabilin nito ng mga tao sa diyos. Itong pag-aangkopkaloob ay ang kaganapan ng pag-angkop.

Example 2:

Die Flucht der Götter muß erfahren und ausgestanden werden. Dieses Beständnis gründet die fernste Nähe zum Ereignis. Dieses Ereignis ist die Wahrheit des Seyns (Heidegger, "Hei Beiträge zur Philosophie [Vom Ereignis]" 27).

The flight of gods must be experienced and endured. The steadfast enduring grounds the most remote nearness to enowning. This enowning is the truth of be-ing (Heidegger, "Contributions to Philosophy: From Enowning" 20). The absconding of the gods must be experienced and endured. This endurance grounds the most remote closeness to the event. This event is the truth of being (Heidegger, "Contributions to Philosophy: Of the Event" 24).

Kailangang danasin at tiisin ang paglikas ng mga diyos. Itong pagtagal-tiis ay siyang nagtatatag sa pinakamalayong kalapitan sa kagananapan ng pagangkop. Itong kaganapan ng pag-angkop ay ang katotohanan ng sinaunang pagmemeron.

Below are two tables showing further examples of translations of Heidegger into Filipino, one of a passage from "Die Frage nach der Technik," and another of a list of some key Heideggerian terms. The limits of space no longer allow me to explain each translation the way I did in the three foregoing examples (see table 1 and 2). 


\begin{tabular}{|c|c|c|}
\hline GERMAN ORIGINAL & $\begin{array}{l}\text { ENGLISH TRANSLATION } \\
\text { (“THE QUESTION } \\
\text { CONCERNING } \\
\text { TECHNOLOGY”) }\end{array}$ & $\begin{array}{l}\text { FILIPINO } \\
\text { (“ANG KATANUNGAN } \\
\text { TUNGKOL SA } \\
\text { TEKNOLOHIYA") }\end{array}$ \\
\hline 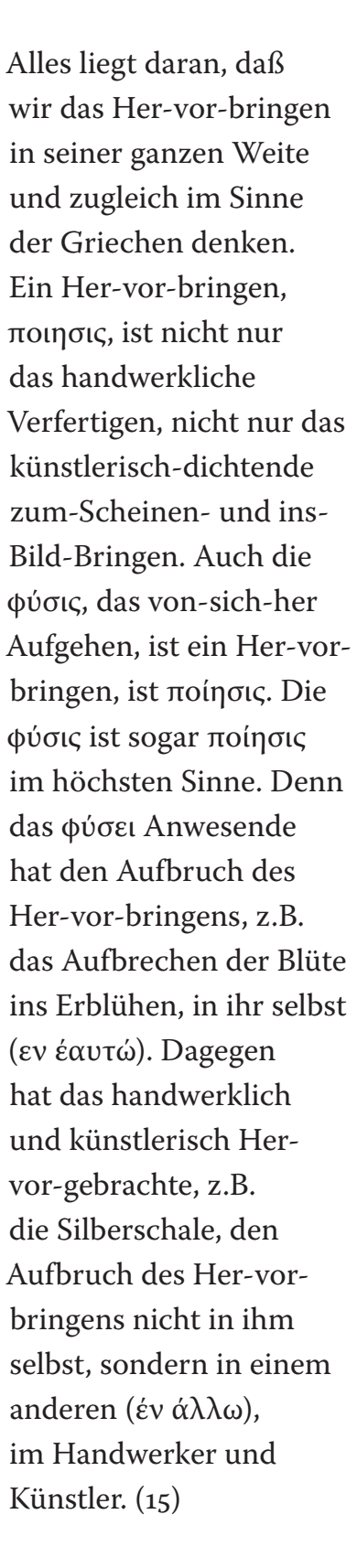 & $\begin{array}{l}\text { It is of utmost } \\
\text { importance that we } \\
\text { think bringing-forth in } \\
\text { its full scope and at the } \\
\text { same time in the sense } \\
\text { in which the Greeks } \\
\text { thought it. Not only } \\
\text { handcraft manufacture, } \\
\text { not only artistic and } \\
\text { poetical bringing into } \\
\text { appearance and concrete } \\
\text { imagery, is a bringing- } \\
\text { forth, poiésis. Physis also, } \\
\text { the arising of something } \\
\text { from out of itself, is a } \\
\text { bringing-forth, poiésis. } \\
\text { Physis is indeed poiésis } \\
\text { in the highest sense. } \\
\text { For what presences by } \\
\text { means of physis has the } \\
\text { bursting open belonging } \\
\text { to bringing-forth, e.g., } \\
\text { the bursting of a blossom } \\
\text { into bloom, in itself (en } \\
\text { hautoi). In contrast, what } \\
\text { is brought forth by the } \\
\text { artisan or the artist, e.g., } \\
\text { the silver chalice, has the } \\
\text { bursting open belonging } \\
\text { to bringingforth not in } \\
\text { itself, but in another (en } \\
\text { alloi), in the craftsman or } \\
\text { artist. (10-11) }\end{array}$ & 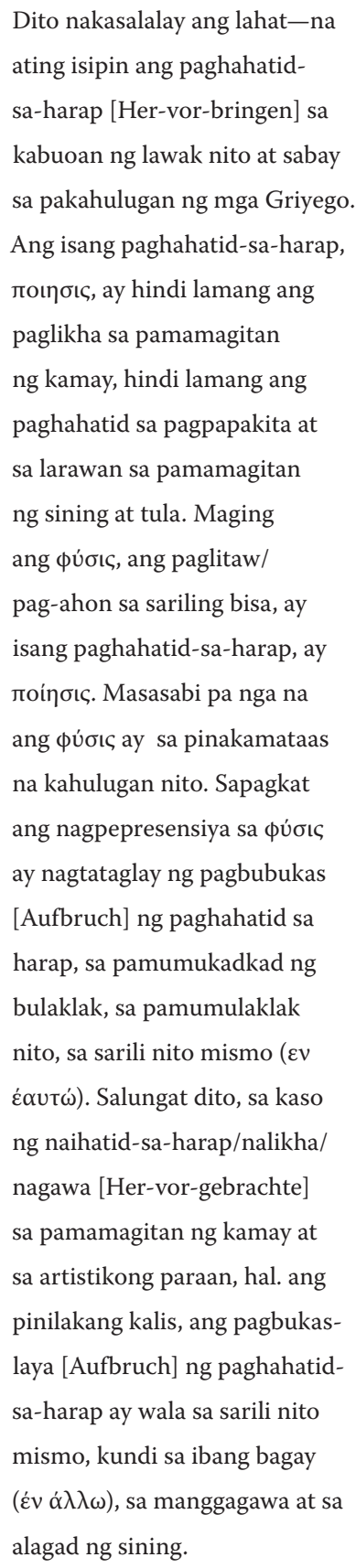 \\
\hline
\end{tabular}

Table 1. Sample Translation: "Die Frage nach der Technik"

Kritika Kultura 21/22 (2013/2014): -016

(c) Ateneo de Manila University

<http://kritikakultura.ateneo.net> 


\begin{tabular}{|c|c|c|}
\hline GERMAN & ENGLISH & FILIPINO \\
\hline Sein & to be & magmeron \\
\hline das Sein & being & pagmemeron \\
\hline ein Seiendes & a being & isang nagmemeron \\
\hline das Seyn & beyng & $\begin{array}{l}\text { sinaunang } \\
\text { pagmemeron }\end{array}$ \\
\hline Ereignis & $\begin{array}{l}\text { event, enowning, event } \\
\text { of appropriation }\end{array}$ & $\begin{array}{l}\text { kaganapan ng } \\
\text { pag-angkop }\end{array}$ \\
\hline $\begin{array}{l}\text { das Anwesen des } \\
\text { Anwesenden }\end{array}$ & $\begin{array}{l}\text { the presencing of that } \\
\text { which presences }\end{array}$ & $\begin{array}{l}\text { ang pag-iral ng umiiral; } \\
\text { ang pagpepresensiya } \\
\text { ng nagpepresensiya }\end{array}$ \\
\hline Dasein & Dasein & Dasein \\
\hline Ge-stell & enframing & pagsasangkahon \\
\hline Geviert & fourfold & sang-apat \\
\hline In-der-Welt-sein & being-in-the-world & $\begin{array}{l}\text { pagsasadaigdig [cf. } \\
\text { sumakabilambuhay, } \\
\text { sumalangit, ergo, } \\
\text { sumadaigdig] }\end{array}$ \\
\hline
\end{tabular}

Table 2. Table of Some Key Heideggerian Terms

\section{Conclusion: Carrying Across to the Other Side, and Pouring Over}

The translation of a German text into Filipino involves the fusion of not only the horizons of the two languages themselves (to borrow the famous formulation of Gadamer), but also the very understanding of translation itself. In the work of translation, the horizons of the two languages are both challenged to expand themselves. It is never just a one-way affair where the language of the original text 
is perceived to colonize the target languages. Rather, in the act of translation, the target language, too, approaches the source language and in so doing becomes capable of enriching it as well. We are aware, for example, how at times the author of a poem is startled by the new meaning or insight that arises when her work is read (orally) by another.

My initial attempts at translating Heidegger into Filipino have also enabled me to become aware of this productive encounter not only between two languages, but also between these two languages' understanding of translation itself, both as an act and a process. Allow me then to conclude this essay by reflecting on this encounter in and through translation.

Listening closely to what the word übersetzen says, Heidegger notes how translation is akin to the ferrying over to the other side of the river. Übersetzen in fact has at least two meanings in German. In the first usage, the word (in this case a non-separable verb) simply means to translate. In the second, the word means "to ferry or to transport across" (this time, it is used a separable verb, e.g. "Das Boot setzt Passagiere über den Fluss," meaning "The boat ferries passengers across the river"). One has to leave one's own shore, as it were, traverse the distance between two languages, and in translation be uprooted and transposed into the very soil of the other shore. And yet in the constant movement between uprooting and taking roots, in the endless to-and-fro play between languages, Heidegger recognizes a shared essential source:

And while I was translating, I often felt as though I were wandering back and forth between two different realities, such that at moments a radiance shone on me which let me sense that the wellspring of reality from which those two fundamentally different languages arise was the same. ("On the Way to Language" 24)

Walter Benjamin seems to be pointing to the Same when he speaks of "pure language" and the "kinship of languages," noting how "this special kinship holds because languages are not strangers to one another, but are, a priori and apart from all historical relationships, interrelated in what they want to express" (255).

On the other hand, the Filipino word for translation, salin, literally means "pour," as in to pour from one container to another (and not in the sense of the pouring of rain, blessings, and the like). When water, for example, is poured from a jug to a drinking glass, or when rice is poured from a sack to a storage bin, the content remains the same, but it takes on a different shape on the whole, even as its parts remain essentially the same. In the pouring of water from a jug to a drinking glass, the shape of the water as a whole changes, from that of the original container, to that of the new one. But the water essentially and substantially remains the same.

Of course, some experience in the storage of liquid substances and even just a bit of scientific knowledge would tell us that it makes a whole lot of difference 
to have the right kind of container for this or that sort of liquid. These days, for example, most consumers are quite aware that it is important to use a BPA-free plastic water bottle in order to keep the water safe. Pouring water from a glass pitcher into a BPA-laden plastic water bottle changes the quality of the water itself, from one of being safe and nutritious, to that of being toxic or hazardous to health. Wine connoisseurs can likewise speak endlessly about the merits of storing vintage wine in oak barrels, and how the resulting product is profoundly affected in terms of color, taste and texture. So, too, in the matter of translation, regarding languages as simply being neutral containers that cannot affect the quality of their contents cannot be taken at face value without running the risk of making simplistic something that is actually complex. In his analysis of William Gass's translation of Rilke, for example, J.M. Coetzee says, "A human language is not a neutral code like a computer language. To be 'English' is to be embedded in the English language and the English language's way of seeing the world. If Hölderlin had 'been English' in any sense, he could not but have written a different poem" (69).

It is thus with some caution that one can say that the Filipino experience of translation seems to have a stronger sense of the text as remaining essentially and substantially the same despite the transfer that happens between two language containers. In the German experience, on the other hand, while indeed the substance remains the same, the emphasis seems to be more on the requirement of uprooting, and the taking roots in the other shore. The difference, as well as the sameness, between two languages in their encounter in translation points to their actuality and at the same time indicates their possibility.

In one of the most famous and thought-provoking lines in Being and Time, Heidegger says, "Higher than actuality stands possibility" (34). Insofar as the possibilities for translation are infinite, perhaps we can paraphrase and say: Higher than the original stands the translation. Apart from possibly being construed as the height of arrogance and a careless, scandalous claim, this proposition surely directly goes against tradition, which universally demands that a translation be faithful to the original. The original remains to be the standard against which all translations are to be measured. And without the original, translations simply cannot be. Benjamin himself expects no less than transparency in translation, so that the original text may be clearly illumined as it wishes to show itself: "A real translation is transparent; it does not cover the original, does not block its light, but allows the pure language, as though reinforced by its own medium, to shine upon the original all the more fully" (260).

So in what sense can we say that higher than the original stands the translation? Not in the sense of superiority or being simply better, but in the sense that the translation as a possibility stands higher than the original as an actuality. Of course one can immediately object and say that the original as an actuality is never really fixed, but always open. But precisely the openness is translation itself. The possibility for understanding the original texts rests on translation. The original 
is preserved by and through translation. Moreover, there is no more certain test of understanding the original than the ability to translate it in one's own language. There is also no greater proof of the importance of a text than the necessity of its translation. A great text always will demand to be translated. Benjamin also sees this when he says that "to some degree, all great texts contain their potential translation between the lines" (263). This "potential translation," contained between the lines of the original text, is precisely its possibility, which stands higher than its actuality. And so, too, every translation will be surpassed by yet another, as the older one may no longer be able to address its audience.

There is perhaps the possibility of understanding translation that recognizes at the same time, on the one hand, the primacy of the original as that which remains to be the measure of every translation and, on the other hand, the necessity of translation on which the very survival of the original depends. To put it in another way, every great text contains within it its potential translation as its own promise of survival. In this context we can see how, in the work of translation, the concept of measure is used in two senses: first, in that the original is the measure of the translation and, second, translation becomes the very measure of the survival of the original text.

Can we read the Filipino translation between the lines of the original texts of Heidegger? We can, for as long as the original contains this potential, for as long it demands this possible translation and, finally, for as long as the translator sees herself as merely responding to the demands of her own language, which in turn demands that something foreign be translated into it. When I thus translate Heidegger into Filipino, I am aware that my fidelity is demanded, not just to the original language as an actuality, but perhaps even more so to the target language as a possibility. Thus, the necessity and impossibility of translation are reconciled only by the internal possibility contained within the original text, a possibility that stands higher than its actuality. 


\section{Works Cited}

Aristotle. The Nicomachean Ethics. Trans. David Ross. Oxford: Oxford UP, 1992. Print.

Bass, Alan. Introduction. Writing and Difference. By Jacques Derrida. London:

Routledge, 2006. ix-xxiii. Print.

Benjamin, Walter. "The Task of the Translator." Selected Writings. Eds. Marcus Bullock and Michael W. Jennings. Trans. Harry Zohn. Cambridge: Belknap / Harvard UP, 1996. 253-263. Print.

Coetzee, J. M. Stranger Shores: Literary Essays 1986-1999. New York: Penguin, 2002. Print.

Emad, Parvis and Kenneth Maly. Foreword. Contributions to Philosophy: From Enowning. By Martin Heidegger. Trans. Parvis Emad and Kenneth Maly. Bloomington: Indiana UP, 1999. xv-xliv. Print.

Ferriols, Roque, S.J. Pambungad sa Metapisika. Quezon City: Office of Research and Publications, Ateneo de Manila U, 1991. Print.

Ferriols, Roque, Nemesio S. Que and Agustin Martin Rodriguez, eds. Pagdiriwang sa Meron: A Festival of Thought Celebrating Fr. Roque J. Ferriols, S.J. Quezon City: Office of Research and Publications, Ateneo de Manila U, 1997. Print.

Gadamer, Hans-Georg. Wahrheit und Methode: Grundzüge einer philosophischen Hermeneutik, 6. Aufl. Tübingen: J.C.B. Mohn (Paul Siebeck), 199o. Print.

Heidegger, Martin. Being and Time: A Translation of Sein und Zeit. Trans. Joan Stambaugh. New York: State U of New York P, 1996. Print.

--. Contributions to Philosophy (From Enowning). Trans. Parvis Emad and Kenneth Maly. Bloomington: Indiana UP, 1999. Print.

--. Contributions to Philosophy: Of the Event. Trans. Richard Rojcewicz and Daniela Vallega-Neu. Bloomington: Indiana UP, 2012. Print.

--. Poetry, Language, Thought. Trans. William Lovitt. New York: Harper, 1977. Print.

--. Gesamtausgabe, Bd. 7. Vorträge und Aufsätze. Frankfurt: Klostermann, 20oo. Print.

--. On the Way to Language. Trans. Peter D. Hertz. San Francisco: Harper, 1971. Print.

--. The Question Concerning Technology and Other Essays. Trans. William Lovitt. New York: Harper, 1977. Print.

--. Gesamtausgabe, Bd. 2. Sein und Zeit. Frankfurt: Vittorio Klostermann, 1977. Print.

--. Gesamtausgabe, Bd. 65. Beiträge zur Philosophie (Vom Ereignis). Frankfurt: Vittorio Klostermann, 1989. Print.

Levine, Susan Jill. "Translation As (Sub) Version: On Translating Infante's Inferno." SubStance 13.1 (1984): 85-94. JSTOR. Web. 5 June 2013.

Olsen, Jan Kyre Berg, Evan Selinger and Søren Riis, eds. New Waves in Philosophy of Technology. Basingstoke: Palgrave, 2009. Print.

Seidensticker, Edward. "On Trying to Translate Japanese." The Craft of Translation. Eds. John Biguenet and Rainer Schulte. Chicago: U of Chicago P, 1989. 142-153. Print.

Spivak, Gayatri Chakravorty. "The Politics of Translation." Outside in the Teaching Machine. New York: Routledge, 2009. 200-225. Print.

Steiner, George. Martin Heidegger. Chicago: U of Chicago P, 1989. Print. 